\title{
Kelase Learning Methods to Improve Flipped Classroom Learning Outcomes
}

\author{
Riana Tangkin Mangesa ${ }^{\mathrm{a}, 1, *}$ \\ ${ }^{a}$ Universitas Negeri Makassar, Makassar, Sulawesi Selatan, Indonesia \\ ${ }^{1}$ rianamangesa@yahoo.com
}

\begin{tabular}{|c|c|}
\hline Article Info & ABSTRACT \\
\hline $\begin{array}{l}\text { Article history: } \\
\text { Received: January 3, } 2018 \\
\text { Revised: March 3, } 2018 \\
\text { Accepted: April 24, } 2018\end{array}$ & $\begin{array}{l}\text { Various teaching methods applied through information and communication technology } \\
\text { (ICT) in learning becomes one important thing to improve learning outcomes. The } \\
\text { application of ICT in learning to be one of the important things for the improvement of } \\
\text { the quality of learning. Various learning methods are also implemented by integrating } \\
\text { ICT in its implementation. One of the methods which used in this research is flipped } \\
\text { classroom. Flipped classroom model in this research uses the development of video and } \\
\text { audio media and e-learning platform (kelase) as online media that can be used to } \\
\text { support flipped classroom model study. This study aims to improve the quality of } \\
\text { student learning outcomes. The method which used in this research is a classroom } \\
\text { action research methods. The results showed an increase in learning, cognitive domain } \\
\text { results, the minimum cycle I and II increased in the affective domain the learning } \\
\text { results of cycles I and II show excellent results. Student perceptions of applying classes } \\
\text { reversed through the use of e-learning kelase are very effective, attractive, very helpful } \\
\text { in understanding the material and assisting self-learning }\end{array}$ \\
\hline
\end{tabular}

\section{INTRODUCTION}

The development of ICT has had an impact on education in the learning process. To be able to utilize ICT in improving the quality of learning, it needs to be realized, through learners and educators who are able to access digital technology and have the knowledge and skills in using digital learning media to help learners achieve academic standards and develop their potential.

Efforts to improve the quality of teaching in a level of education, not apart from the various factors that affect teaching and learning activities in the classroom. Microquality improvement is closely related to professional behavior an educator in the teaching process. This is a reflection of commitment to control the implementation of values, attitudes and professional behavior.

Every learning process undertaken by learners will produce learning outcomes. In the learning process, as educators play a big role and responsibility in order to help improve the success of learners is influenced by the quality of teaching
Supported by some opinions of experts, that learning is an educator conscious effort to teaching learners in order to improve learning outcomes. Thus teaching and learning process that aims to improve learning outcomes requires the ability to plan strategic components and learning media, tailored to the conditions and school environment.

This will be very easy if the teacher is able and skilled using ICT, because it can determine strategies and media accordance with the needs in the learning process. Thus the function of the media, as a presenter and learners messages, media learning in certain cases, can represent the learners present the information learned at the learners, (B. R. Joyce, Weil, \& Calhoun, 2000).

Application of ICT in education is an innovation that contributes greatly to the change in the learning process. A teacher is effective if can accomplish the planned goals and assigned tasks in accordance with school goals. Teacher one of the key elements in every school and effective teaching is one of the main propeller for school improvement, (Ko, Sammons, \& Bakkum, 2016). 
Through the development of ICT learning process is very able to become the main facilitator to improve the quality of education in Indonesia. Because ICT has the ability of distance learning. So that allows learners more motivated to learn by ICT-based learning method.

Thus the participants who heavily utilized technology in their classroom, generally felt that it allowed their teaching to be tailored for various paces, levels, ease of access to information and spontaneous learning opportunities. Study that learners who use technology in their classes, generally feel that it allows their teaching tailored for various steps, levels, easy access to information and spontaneous learning opportunities, results reset (Bertram \& Waldrip, 2013).

The people of $21 \mathrm{st}$ century faces of increasing sophisticated technology. The development of this technology indicates that science is growing and competition is getting higher, so that the necessary skills have to be able to compete and survive. The skills are hard skills and soft skills. One attempt to acquire these skills is through the educational process which summarized in the learning process.

Principles of Higher Education, the National Standards, namely: 1) interactive; 2) holistic; 3) integrative; 4) scientific; 5) contextual; 6) thematic; 7) Effective and 8) is focused to student (Direktorat Pembelajaran dan Kemahasiswaan Direktorat Jenderal Pendidikan Tinggi Kementerian Pendidikan dan Kebudayaan, 2014).

Wolf, Lutz-Christian, Jenny Chan, introduced a method is called a flipped classroom learning; Students watch the videos outside the classroom before or after coming to class where the freed time can be devoted to interactive modules such as $\mathrm{Q}$ \& A sessions, discussions, exercises or other learning activities (Wolff \& Chan, 2016).

This shows that students who watch the video before or after learning activities in the classroom can use more time for question answer, session discussing assignments and other learning activities. Thus the learning process is not limited by time and space.

Utilization of e-learning kelase can provide many easiness in learning. Kelase aims to provide learning space, as a medium that promotes social and collaborative aspects, rich learning experiences, facilitates governance of the educational process, monitoring the development of learning processes, and bridges communication between teachers, students and parents. By using Kelase service, then the learning process can be done anywhere and anytime.

Model flipped classroom, effectiveness of used in the learning process, because students can learn according to the environment so as to attract and produce higher achievement. This is supported by over 30 articles comparing traditional and reverse classroom learning (Bormann, 2014). Application of the method flipped classroom by using e-learning kelase can be used as a method of learning that can improve the quality of learning outcomes.

This study shows an increase of cognitive domain of learning and affective domain of learning outcomes. Thus flipped classroom method can be one method of learning that can be used to improve the quality of student learning outcomes.

Supported results of the study, (Marlowe, 2012) stated that learning using Flipped Classroom method gives freedom so that it can reduce stress level in learning, because it gives freedom to choose task and exploring what they consider more attractive.

\section{METHOD}

This type of research is the Classroom Action Research. Aiming to improve or enhance the quality of learning. Classroom Action Research is research that combines several disciplinary measures of inquiry, to understand what happened, while engaged in a process of improvement and change (Vaccarino, Comrie, Murray, \& Sligo, 2007). This classroom action research using two cycles. The expected outcomes of each cycle are:

\section{A. First Cycle}

\section{1) Identify The Problem}

Outcome that be expected at this stage is to know the problems that arise in order to be identified for the problem solving process.

\section{2) Planning}

Outcome that be expected at this stage is the emergence' plans that can be used to overcome the problems that arise in learning.

\section{3) Action}

Outcome that be expected at this stage is the lack of action or implementation of plan that has been created to address learning problems.

\section{4) Observation}

Outcome that be expected at this stage is the student learning outcomes obtained through observation activity in the classroom and on the assessment of assignments and quizzes.

\section{5) Reflection}

Outcome that be expected at this stage is recommendation for the next stage. Solved recommendation contain problem that have or have not been solved. Assessment of the action is given as well as the things that need to be improved and what actions will be given in the next cycle.

\section{B. Second Cycle}

Cycle II is performed as the first cycle, in accordance with the result of reflection which the aim is to increase student learning outcomes.

\section{RESUlT AND DISCUSSION}

\section{A. Learning Outcomes Cognitive Domain}

The results of the implementation of the first cycle and the second cycle showed the increase learning outcomes in the cognitive domain of students. Seen from the average score of students in the first cycle of $62.5,17$ or in category $\mathrm{B}+$ and 
the second cycle of the average point of 80 or a student currently on a category $\mathrm{B}+$. Minimum point, maximum point, and the average point of the class in the first cycle and the second cycle are shown in Table I.

Cognitive learning outcomes of students in the application domain flipped classroom by using e-learning kelase show an increase. The minimum point of a pre-test on the first cycle is 40 , whereas in the second cycle minimum point is 60 , the maximum point of the first cycle is 60 increase to 85 in the second cycle, and the average point of the pre-test on the first cycle 40 increase to 50 in the second cycle. The minimum point of the post-test in both cycles, each of which is 55 and 70 , the maximum point of the post-test two cycles respectively 55 and 70, the maximum point of the second cycle was 90 and the mean (average) grade on the post-test the second cycle is 62.5 and 80 .

Thus there is an increase in student outcomes with the application of flipped class by using e-learning kelase as a medium in the learning process. Multimedia technology can facilitate interactive learning, therefore an interactive multimedia concept can support the development of multimedia systems (Pahl, 2004). The preliminary results presented can show that reversing the classroom model has a positive impact on student grades. Minimum, maximum and average point of post-test cycle I and II can be presented in a bar chart in Figure 1.

The minimum point, maximum and mean post-test two cycles are presented in Figure 1 above shows a comparison is the minimum point of the first cycle is higher than the minimum point of the second cycle of 55 to 65 , the maximum point of the second cycle of the same, namely 90 and the average point of the class increased from 62.5 to 80 in the first cycle to the second cycle.

It is suggested that teachers should build up the opportunity to repeat and review the rules and key concepts, in facilitating student retention and understanding of the topic (B. Joyce, Calhoun, \& Hopkins, 2008). Thus the application of the model flipped classroom through the use of e-learning kelase can improve student learning outcomes of cognitive domain in the subject.

According research results (Overmyer, 2014), indicating that there is no statistically significant difference. But it appears in two groups of students in the Flip class better than the students in the traditional class.

Subsequent research on various aspects of learning is a flipped learning implementation, framed by theoretical frameworks and evaluation methods, in teaching techniques still needed to build of pedagogy learning (Karabulut - Ilgu, Jaramillo Cherrez, \& Jahren, 2018)

TABLE I. DESCRIPTIVE ANALYSIS OF LEARNING OUTCOMES COGNITIVE DOMAIN CYCLE I AND CYCLE II

\begin{tabular}{ccccccc}
\hline \multirow{2}{*}{ Test } & \multicolumn{3}{c}{ Cycle I } & \multicolumn{3}{c}{ Cycle II } \\
\cline { 2 - 7 } & Min & Max & Mean & Min & Max & Mean \\
\hline Pre-test & 40 & 60 & 50 & 60 & 70 & 65 \\
Post-tes & 55 & 70 & 62.5 & 70 & 90 & 80 \\
\hline
\end{tabular}

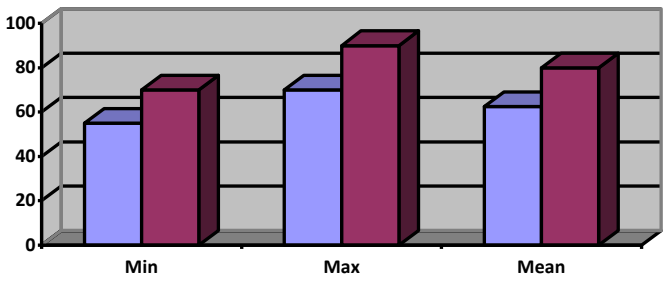

Fig. 1. Point Minimum, Maximum, and Mean Post-test Cycle I and Cycle II

\section{B. Learning Outcomes Affective Domain}

Affective domain of learning outcomes flipped classroom model application by using of e-learning kelase increased. Table frequency distribution affective domain of learning outcomes cycle I and II show very good results in the first cycle and the second cycle of each is 2 or $6.25 \%$ and 11 people or $34,4 \%$, both categories in the first cycle of 28 people or $87.5 \%, 20$ people or $62.5 \%$ in the second cycle and enough categories 2 or $6.25 \%$ of cycles I and 1 people or $3.21 \%$ in the second cycle. These results indicate that there is an increase in very good category, but decreased in both categories and increased in the category enough.

Affective domain of learning outcomes gained through assessment in the implementation of the learning process. Thus the application of the model flipped classroom through the using of e-learning kelase can improve learning outcomes but should be optimized further learning. Data in Table 2 can also be presented in a bar chart like Figure 2 .

Attitudes and values to be achieved in the learning data communication that is synchronized with the application of the model flipped classroom teaching model is shown in the Figure 3.

TABLE II. FREQUENCY DISTRIBUTION CYCLE LEARNING OUTCOMES AFFECTIVE DOMAIN

\begin{tabular}{ccccc}
\hline \multirow{2}{*}{ Category } & \multicolumn{2}{c}{ Cycle I } & $\boldsymbol{c}$ & Cycle II \\
\cline { 2 - 5 } & $\boldsymbol{f}$ & $\boldsymbol{\%}$ & 11 & $\%$ \\
\hline Very Good & 2 & 6.25 & 20 & 34.38 \\
Good & 28 & 87.5 & 1 & 62.5 \\
Sufficient & 2 & 6.25 & 0 & 3.21 \\
Deficient & 0 & 0 & & 0 \\
\hline
\end{tabular}

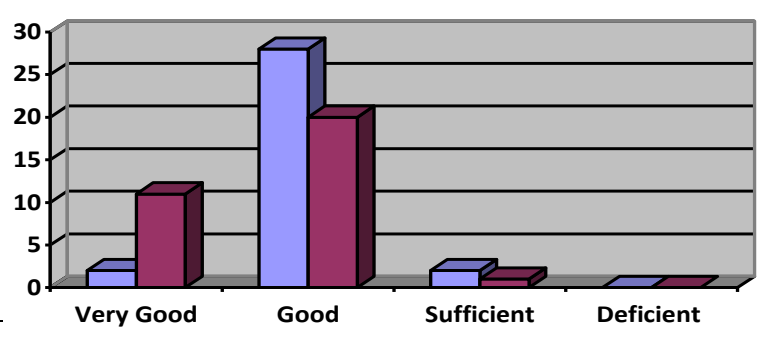


Fig. 2. Distribution of Frequency Learning Outcomes Domain Affective Cycle I and Cycle II

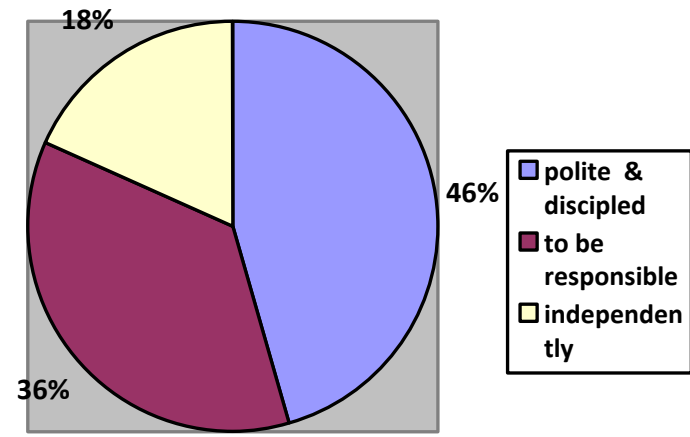

Fig. 3.

Percentage of attitudes on the application flipped classroom methods

\section{Perception of Students}

Students' perception for application of the model flipped learning via e-learning kelase need to know. Perception of students in this study were obtained by requesting a written response from students at the end of the implementation of the second cycle.

The questions are posed to know the response of the students, the convenience and suitability according to the needs of learning styles of each student. Media learning can be interpreted as a tool in teaching, as well as means messenger of learning resources to learn the message recipient.

The results of the study (Amresh, Carberry, \& Femiani, 2013), show that the learning model flipped in classroom has a positive impact on the student's score. Student self-efficacy also increases, but since the reversing approach is not used for the entire duration of the class, there is a possibility of improper correlation between the student's own approach and learning

\section{CONCLUSION}

Flipped classroom methods through the using of e-learning kelase can improve learning outcomes. Participants' perceptions on the application of methods flipped classroom through the use of e-learning kelase is highly effective, efficient, make it easier to understand the material and very helpful in independent learning, delivery of content is not limited by time and the delivery of material not boring.

Appropriate the results showed that the students' perceptions of the reversed classes are rather diverse, but generally positive overall. Students tend to choose private lectures for video lectures, but prefer interactive class activities during lectures (Bishop \& Verleger, 2013).

The obstacle experienced which in the application of methods flipped classroom through the use of e-learning kelase is a lack of readiness of students to learn before entering the lecture hall so that the learning process is less interesting discussion. The teacher's obstacles is short time to monitor the activity of the classroom in space online or e- learning kelase so the response to the students are still lacking. Therefore, further research is required by using experimental methods, as recommended (Bishop \& Verleger, 2013), for further research, design classroom activities, using controlled experiments or experimental quasi experiments, investigating of learning outcomes.

\section{References}

Amresh, A., Carberry, A. R., \& Femiani, J. (2013). Evaluating the effectiveness of flipped classrooms for teaching CS1. In Frontiers in Education Conference, 2013 IEEE (pp. 733-735).

Bertram, A., \& Waldrip, B. (2013). ICT for ICT's sake: Secondary teachers' views on technology as a tool for teaching and learning. Australian Educational Computing, 28(1).

Bishop, J. L., \& Verleger, M. A. (2013). The flipped classroom: A survey of the research. In ASEE national conference proceedings, Atlanta, GA. Vol. 30. No. 9. (pp. 1-18).

Bormann, J. (2014). Affordances of Flipped Learning and Its Effects on Student Engagement and Achievement. University of Northern Iowa.

Direktorat Pembelajaran dan Kemahasiswaan Direktorat Jenderal Pendidikan Tinggi Kementerian Pendidikan dan Kebudayaan. Panduan Penyusunan Capaian Pembelajaran Lulusan Program studi (2014).

Joyce, B., Calhoun, E., \& Hopkins, D. (2008). Models of learning, tools for teaching (3rd editio). Buckingham: McGraw-Hill Open University Press.

Joyce, B. R., Weil, M., \& Calhoun, E. (2000). Models of Teaching (6 Edition). Allyn \& Bacon.

Karabulut- Ilgu, A., Jaramillo Cherrez, N., \& Jahren, C. T. (2018). A systematic review of research on the flipped learning method in engineering education. British Journal of Educational Technology, 49(3), 398-411.

Ko, J., Sammons, P., \& Bakkum, L. (2016). Effective teaching. Reading, Berkshire: Education Development Trust.

Marlowe, C. A. (2012). The Effect of the Flipped Classroom on Student Achievement and Stress. Bozeman, Montana.

Overmyer, G. R. (2014). The flipped classroom model for college algebra: Effects on student achievement. Colorado State University: Fort Collins.

Pahl, C. (2004). A Taxonomy for Interactive Educational Multimedia. Dublin 9 , Ireland

Vaccarino, F., Comrie, M., Murray, N., \& Sligo, F. (2007). Action Research Reflections: The Wanganui Adult Literacy and Employment Project. Wellington and Palmerston North, New Zealand.

Wolff, L.-C., \& Chan, J. (2016). Flipped classrooms for legal education. Springer. 